\title{
Economics and interdisciplinarity: an open-systems approach ${ }^{1}$
}

\author{
Economia e interdisciplinaridade: \\ uma abordagem em sistemas abertos
}

VÍTOR NEVES*

\begin{abstract}
RESUMO: Este é um texto sobre economia e interdisciplinaridade. Tem em conta a pluralidade de significados que a prática da interdisciplinaridade assumiu em economia, discute por que a interdisciplinaridade é essencial para o estudo da economia e analisa dois modelos do que a interdisciplinaridade deve ser em economia. Também é feita referência aos obstáculos inerentes à prática da interdisciplinaridade. Seu objetivo final é mostrar por que a economia (como um objeto de estudo), sendo um sistema aberto, exige um entendimento pluralista e de economia política da "economia".

PALAVRAS-CHAVE: Economia; interdisciplinaridade; sistemas abertos; conexões; pluralismo.

ABSTRACT: This is a text on economics and interdisciplinarity. It takes account of the plurality of meanings that the practice of interdisciplinarity has assumed in economics, discusses why interdisciplinarity is essential to the study of the economy and analyzes two models of what interdisciplinarity should be in economics. Reference is also made to the obstacles inherent in the practice of interdisciplinarity. Its ultimate goal is to show why the economy (as an object of study), being an open system, cannot be left to economists alone requiring, instead, a pluralistic, political economy understanding of the 'economic'. KEYWORDS: Economics; interdisciplinarity; open systems; connections; pluralism. JEL Classification: A12; B4.
\end{abstract}

\section{INTRODUCTION}

The relationship that economics establishes with "contiguous" disciplines is fundamental to understand the nature of economics itself. Discussing that relationship entails thinking the definition of the boundaries and connections that we

\footnotetext{
${ }^{1}$ This work was supported by the Portuguese Foundation for Science and Technology, Strategic Project [UID/SOC/50012/2013]

* Assistant Professor at the School of Economics and Researcher of the Centre for Social Studies of the University of Coimbra, Portugal. Email: vneves@fe.uc.pt. Submitted: 21/September/2015; Approved: 17/March/2016.
} 
may or should establish and, ultimately, this implies thinking the very nature of what we call "the economic". Any discussion of interdisciplinarity in economics implies talking about the nature of its actual subject matter. It is, after all, a discussion about disciplinarity. It is this idea that I intend to explore in this text.

It could always be argued that discussing the issue of interdisciplinarity is nothing more than a dilettante exercise, useless or irrelevant for the actual practice of research in economics. I do not think so. As I have argued elsewhere, ${ }^{2}$ the specific way that interdisciplinarity is considered has crucial implications on the way that economics is practiced (and taught).

Interdisciplinarity is a word with many meanings and can be considered from many perspectives. ${ }^{3}$ In this text, I shall start by making a brief reference to the recent evolution of economics with respect to its boundaries, from what is referred to as "economic imperialism" up to the intense processes of reciprocal fertilization in course. The plurality of meanings that the practice of interdisciplinarity has embodied in economics should become clear in this context. Next, I shall present the reasons why, in my view, interdisciplinarity is indispensible in the study of the economy. Two models will then be analyzed, regarding precisely what interdisciplinarity in economics should constitute: one emphasizes the need for interchange with "contiguous" disciplines with a view to gaining a better understanding of the economic system, albeit while maintaining the respective disciplinary autonomy (let us call this the multidisciplinary model); the other, more radical, defends the need to transcend the current disciplines, moving towards a unified social science (let us call this the transdisciplinary model). Attention will also be drawn to the obstacles inherent to the practice of interdisciplinarity, starting with the institutional, but also those arising from the different disciplinary cultures and their corresponding ways and habits of thinking and arguing, and the difficulties associated to the fact that disciplines are, by their very nature, internally conflictual. A very brief mention will also be made to the issue of interdisciplinarity as interparadigmaticity and the fundamental relevance of a pluralist understanding of science will be stressed.

It is hoped that, at the end, it shall become clear that, although, as someone said, the boundaries of the mind and habit are more difficult to tear down than the boundaries between States, it is crucial to understand why the economy (as an object of study) cannot be left to economists alone requiring, instead, a pluralist, open-systems political economy approach.

\section{PRACTICES OF INTERDISCIPLINARITY IN ECONOMICS}

Any discipline, in order to become established, needs to define its domain - its core interests and questions (its focus of interest and theoretical problematic) - and

\footnotetext{
${ }^{2}$ Neves, 2012a.

${ }^{3}$ Arena et al., 2009; Kerstenetzky and Neves, 2012; Pombo, 2004a; Strober, 2011.
} 
its conceptual and methodological foundations. This implies defining boundaries relative to other disciplinary discourses. It implies, in greater or lesser degree, some sort of "interdisciplinary isolations". ${ }^{4}$ As a result, we refer, for example, to economic discourse in contrast to the discourse of Physics, Biology, Psychology, Sociology, Political Science, History, etc.

The constitution of economics as a modern science, from the publication of the famous Wealth of Nations, ${ }^{5}$ by Adam Smith in 1776, up to the important Essay on the Nature and Significance of Economic Science, by Lionel Robbins, ${ }^{6}$ can be characterized as a long process of definition and autonomization of a specific area of studies, with a well delineated theoretical object and its own conceptual structure and research method.

The discipline of economics has an extremely rich and multifaceted history, with numerous actors and varied theoretical and methodological contributions, which obviously shall not be recalled here. Nonetheless, merely for illustrative purposes, some of the key milestones of this process are noted below:

i. The "marginal revolution" which took place during the 1870 s - with the redefinition of the "economic problem", shifting the focus of attention away from the sphere of production and the study of the origin of wealth, economic surplus and the issue of distribution (as occurred in classical political economy) and towards the sphere of exchange and the study of the market and prices as the fundamental mechanism of economic coordination and resource allocation - and the progressive transformation, in the late nineteenth century/early twentieth century, of Political Economy, a branch of Moral Philosophy, into more "scientific" Economics; ${ }^{7}$

ii. The eminent role played by Alfred Marshall, not only due to his important work of theoretical consolidation, but also his valuable contribution to the creation, in 1903, at the University of Cambridge (United Kingdom), of a programme of studies in economics (Economics and

\footnotetext{
${ }^{4}$ According to Mäki 1992 and 2004, "isolation" occurs when something, a set of entities, X (the "isolated field"), is removed from the influence of the rest of the universe, Y (the "excluded field"). X, the isolated field, and Y, the excluded field, exhaust all relevant possibilities. The isolations may be theoretical ("thought experiments") or material ("experimental isolations" or, more rarely, "spontaneous isolations"). "Theoretical isolation" refers to the operation through which, in the construction of a concept, model or theory, a system, relationship, process or feature is (intellectually) isolated from other possible influences. Interdisciplinary isolations thus define the domain (and delineate the boundaries) of a given disciplinary discourse in relation to other disciplinary domains. Naturally, there are different strategies of isolation, which determine exactly what is isolated (i.e., where the boundary line between $\mathrm{X}$ and $\mathrm{Y}$ is defined) and how this is carried out.

${ }^{5}$ An Inquiry into the Nature and Causes of the Wealth of Nations.

${ }^{6}$ Robbins, 1932.

${ }^{7}$ Vaggi and Groenewegen, 2003, namely chapter 17.
} 
Politics Tripos) that was separate from the traditional Moral Sciences Tripos in which studies on the economy had previously been placed; ${ }^{8}$

iii. The famous methodenstreit, a long controversy triggered by the debate between Carl Menger (Austrian school) and Gustav von Schmoller (German historical school), lasting from the 1880s through to the early twentieth century, vigorously exposing two conflicting perspectives on the study of economics - one analytical, focused on theoretical abstraction (marginalism), the other emphasizing the need of close attention to historical facts and institutional aspects; ${ }^{9}$

iv. Finally, but of no lesser relevance, the methodological work of Lionel Robbins, ${ }^{10}$ with its radical separation between fact and value (between economic science and Ethics), and the "consensus" or "implicit contract" ("gentlemen's agreement" in the words of Ingham) $)^{11}$ established among economists and sociologists based on Talcott Parsons and Robbins concerning a division of labour centred on the analytical perspective of each of its disciplines ("the analytical factor view"), with each focused on a differed aspect (factor) of social action - economics, "the science of choice", studying the so-called rational choice between scarce resources to achieve set objectives ("logical" action, following Pareto); Sociology, "the science of social action", investigating the role of ultimate goals and their underlying attitudes and values. ${ }^{12}$

In this process of definition and separation as a specific area of studies, economics seeks to forge itself as a rigorous science, increasingly mathematical, ${ }^{13}$ in the image of Physics - the "hardest" of the "soft" sciences, as shall later be said and adopts a strategy aimed at analytically isolating the study of the "economic" sphere from the influence of structures and social relations (thus separating it from the rest of the social sciences). In the words of Ben Fine,,${ }^{14}$ the discipline constituted itself as "Fortress Economics".

With Robbins, economics becomes, above all, a way of thinking, a method of analysis. ${ }^{15}$ The economy is analyzed in terms of (efficient) equilibrium solutions for problems of rational choice of allocation of scarce resources with alternative uses

\footnotetext{
${ }^{8}$ Groenewegen, 2007.

${ }^{9}$ Swedberg, 1990; Hodgson, 2001.

${ }^{10}$ Robbins, 1932.

${ }^{11}$ Ingham, 1996, p. 244.

${ }^{12}$ Hodgson, 2008; Velthuis, 1999.

${ }^{13}$ Mirowski, 1991.

${ }^{14}$ Fine, 1997.

${ }^{15}$ Neves, 2010.
} 
(optimization), as a result of the aggregation of behaviours of individual agents considered in an atomistic manner (the model of rational choice).

Nevertheless, its scope of study shall continue, up to the late 1950s, to be the market and the price mechanism (alongside monetary phenomena and economic cycles). The truth, however, is that nothing in the conceptualization of economics by Robbins imposes such limitation. This was clearly understood by various authors, such as Gary Becker and others, ${ }^{16}$ who, as of the second half of the 1950s, embarked on a path of transgression of the old boundary of economics as science of the market, based on the "export" of the model of rational choice to areas traditionally considered as "non-economic" (educational choices, family, demographic evolution, crime, discrimination, political processes, law, etc. $)^{17}$ and on the application of the principles of individual optimization to the analysis of institutions and collective behaviour. For these authors, the social is nothing more than an extension of the individual. The rational choice model can and should be universalized in the context of a new "economic approach to human behaviour". Becker - perhaps the most notable and influential representative of this new approach was to say on this issue: ${ }^{18}$

"all human behavior can be viewed as involving participants who maximize their utility from a stable set of preferences and accumulate an optimal amount of information and other inputs in a variety of markets.”

And, later, in his Nobel Lecture: ${ }^{19}$

"The rational choice model provides the most promising basis presently available for a unified approach to the analysis of the social world by scholars from different social sciences."

Thus, it is indeed an "economic imperialism" that is involved in this attempt to redefine economic boundaries that occurs from the 1950s onwards, based on the export of the dominant method in economics to other social domains. ${ }^{20}$ Interdisciplinarity, from this perspective, is nothing more than a project of explanation of all social behaviour through the use of instruments of economic analysis. Jack

\footnotetext{
${ }^{16}$ Such as Anthony Downs, Gordon Tullok or Mancur Olson.

${ }^{17}$ See, for example, Becker, 1976, Downs, 1957, Posner, 1972.

${ }^{18}$ Becker, 1976.

${ }^{19}$ Becker, 1993.

${ }^{20}$ Here, the term that has become conventional in the literature has been used, inclusively by advocates of this approach, such as Edward Lazear (2000). However, as noted by Olson and Kähkönen (apud Ben Fine, 2002, p. 188), this terminology is inadequate since there is no use of force or denial of free choice. These two authors propose, as an alternative, the suggestive metaphor of economics as a metropolis extending its influence to the rest of the social science suburbs.
} 
Hirshleifer, in The Expanding Domain of Economics, ${ }^{21}$ actually refers to economics as the "universal grammar" of social science, considering that "non-economic" social sciences will soon tend to become indistinguishable from economic science. Edward Lazear, another enthusiastic advocate of economic imperialism, stated more recently:22

"The goal of economic theory is to unify thought and to provide a language that can be used to understand a variety of social phenomena".

Economic imperialism is currently still a project with impact within the discipline and, especially, successful in terms of its media coverage. ${ }^{23}$ In truth, however, the transgression of disciplinary boundaries which has taken place over the last decades, contrary to the reductive desires of the defenders of economic imperialism, has not followed a strict logic of export, but should rather be described as a movement of twofold (or even multiple) directions, an "export/import" model" ${ }^{24}$ or of mutual "inspiration", ${ }^{25}$ characterized by intense and diverse processes of conceptual and methodological contamination and reciprocal fertilization.

Merely as illustration:

i. The application of experimental psychology and neuroscience to the study of cognitive processes and economic behaviour, of the architecture of choice and economic design of markets. ${ }^{26}$

ii. The incorporation in economics of approaches based on the science of complexity with approximations between Physics and Economics (e.g. chaos theory and non-linear dynamics; agent-based computational economics). ${ }^{27}$

iii. The application of game theory to studies on conflict, cooperation and strategic behaviour, for example in the field of Industrial Organization. ${ }^{28}$

These interdisciplinary exchanges have implied profound changes in the assumptions, concepts and practices of economics. Key concepts, such as rationality and equilibrium, and their relevance have been significantly rethought. The boundaries with some disciplines have become much more fluid (which is the case, for instance, between Economic Sociology and the institutional approach to

\footnotetext{
${ }^{21}$ Hirshleifer, 1985.

${ }^{22}$ Lazear, 2000, p. 142.

${ }^{23}$ See, for example, the success of Freakonomics (“The Hidden Side of Everything”), http://freakonomics.com/.

${ }^{24}$ Davis, 2006.

${ }^{25}$ Frey and Benz, 2004.

${ }^{26}$ Santos, 2010 and 2012.

${ }^{27}$ Fontana, 2009; Arthur, 2013; Graça and Lopes, 2010.

${ }^{28}$ Van Damme, 1999; Sugden, 2001.
} 
economics ${ }^{29}$, actually leading, in some cases, to the development of new disciplinary areas and new or renovated sub-disciplines. Particularly evident examples are found in the rapid growth of experimental and behavioural economics and neuroeconomics (as a result of the new relationship with Psychology and neuroscience), Complexity Economics, the development of "Law and Economics" (incorrectly confused, in my view, with the reductive "economic analysis of law"), a new Comparative Political Economy (with studies on varieties of capitalism), as well as the so-called normative turn in Economics ${ }^{30}$ with the return to Ethics.

Also in economics it can be stated that many of the most innovative works have been associated to processes of reciprocal fertilization at the boundaries of the discipline, as clearly illustrated by some of the most recent laureates of the Prize in Economic Sciences in Memory of Alfred Nobel. ${ }^{31}$

Moreover, it must be pointed out that there is still enormous potential for the application of these new developments in the most varied areas of economics. ${ }^{32}$ Economics is currently a lively discipline ${ }^{33}$ where it is hardly risky to foresee that these processes of interdisciplinary fertilization shall give rise, in the near future, to profound transformations in the current state of the discipline.

\section{WHY IS INTERDISCIPLINARITY INDISPENSIBLE?}

"Interdisciplinary isolations" are inevitable. Knowledge, as emphasized by Loasby, ${ }^{34}$ "grows by division". The relevance of the division of labour expounded by Adam Smith in the Wealth of Nations is equally valid with respect to knowledge. Our cognitive limitations (and the different competencies and skills that we possess) undoubtedly impose a division of scientific labour. What we may know is necessarily scattered. But it is also incomplete and partial. There is a well-known parable of the blind men who, clinging to their partial perceptions, are incapable of identifying an elephant. ${ }^{35}$ Therefore, as Loasby also argued: ${ }^{36}$

"Because different people can develop different skills, a knowledge-rich society must be an ecology of specialists; knowledge is distributed

\footnotetext{
${ }^{29}$ See, on this issue, Dequech, 2012.

${ }^{30}$ Kerstenetzky, 2012.

${ }^{31}$ Better known, albeit incorrectly, as the Nobel Prize in Economics.

${ }^{32}$ Diamond and Vartiainen, 2007; Holt et al., 2011.

${ }^{33}$ This is obviously not incompatible with a critical view that, at the same time, emphasizes the discipline's responsibilities - or, perhaps we should say, of its mainstream - in the recent Great Recession.

${ }^{34}$ Loasby, 1999, p. 135.

${ }^{35}$ See, for example, at http://www.cs.princeton.edu/ rywang/berkeley/258/parable.html and https:// pt.wikipedia.org/wiki/Anekantavada.

${ }^{36}$ Loasby, 1999, p. 130.
} 
[...] and being distributed it can grow, provided that it is sufficiently co-ordinated to support increasing interdependencies." (my emphasis)

The loss of relevant connections - the interdependencies referred to by Loasby in the quotation above - is effectively a problem of the highest importance. Knowing is establishing connections.

Interdisciplinary isolations imply exclusions. Many possible connections between aspects of reality are discarded, supposed to be inexistent or irrelevant, in order to pay attention to others. ${ }^{37}$ The choice of the "isolated field" of a science which includes the set of explanatory items (explanantia) and the set of items to be explained (explananda) - also consists of an operation of exclusion. This happens, in general, by mere omission. The excluded items or relations are ignored and fall outside the scope of the discipline, without any mention. They become a "field of silence". ${ }^{38}$

As what can be explained by a science is limited by the selected set of explanatory items, ${ }^{39}$ the interdisciplinary isolations involved in this process, both in the choice of the explananda and explanantia - and the consequent boundary lines derived thereof - are crucial.

Various interdisciplinary isolation strategies are observable within each discipline - and economics is obviously not an exception. A contrast is evident, for example, in the approaches used by Gary Becker and Ronald Coase. Becker enlarged the scope of study of economics, including in it all human behaviour in view of scarcity - educational choices, family, crime, etc. - seeking to explain behaviour that, up to this point, had been considered "non-economic", based on the same rational choice model that economists had long been applying in the analysis of the "economic" behaviour of consumers and producers in markets. Ronald Coase, to the contrary, called for an enlargement of the explanatory resources of economists - including in them any useful contribution from other disciplinary fields, namely Law - with a view to a more suitable explanation of the traditional object of study of economics - the "economic system". ${ }^{40}$

Significant controversies have, indeed, occurred throughout the entire history of economics, both concerning the choice of items to be explained and the choice of the items that are acceptable as constituting explanatory factors. Very frequently, disputes have to do with different conceptions of the nature of the object of study.

Boundaries are, in fact, a human construction, more or less artificial. The world has no boundaries; it forms a single ontological unity. Isolations apply only to our

\footnotetext{
${ }^{37}$ Loasby, 2003, p. 294.

${ }^{38}$ Mäki, 1992, pp. 335-6.

${ }^{39}$ Mäki, 2004, p. 322.

${ }^{40}$ Of course, Coase's strategy for an opening of the discipline still entails some sort of interdisciplinary isolation.
} 
thoughts and representations of the real world; not to the phenomena themselves. ${ }^{41}$ The "economy" that we wish to study (the "economic system", following Coase) is an open system.

A system is here understood as a set of elements (things or ideas) interlinked by a network of connections forming a coherent whole - a structure with connections. ${ }^{42} \mathrm{~A}$ system can be closed or open. The first is a system without any relations with its surrounding environment or with other systems, a circumscribed domain, neither affected by external forces nor affecting them. In contrast, an open system is a system that, in some manner, to a greater or lesser extent, is connected with the exterior (the boundaries, if they exist, are fluid and permeable). ${ }^{43}$

The challenge, therefore, is how to adjust theory to the nature of the object of study. Scientific practice always presupposes an underlying ontology. ${ }^{44}$ Our conception of social reality - i.e. our social ontology - delineates the way we theorize the objects of study. The logic of thought should be consistent with ${ }^{45}$ the logic that we assume exists in the social reality (the onto-logy). ${ }^{46}$

It would seem obvious, after what has been stated above, that we need to $d e$ compose the object of study. But how can we segment reality without losing fundamental connections? Apart from the ontological restriction ${ }^{47}$ mentioned above - our cognitive limitation and the centrality of the interconnections of the real world - we need an epistemology of interdisciplinarity.

\section{MODELS OF INTERDISCIPLINARITY IN ECONOMICS: MULTIDISCIPLINARITY OR TRANSDISCIPLINARITY?}

The most difficult issue that we are confronted with when we wish to construct an epistemology of interdisciplinarity is, as noted above, determining the way that the reality-object of study is segmented with a view to enhancing the interconnections. Or, in other words: where and how do we draw the boundary lines?

This section focuses on two major models concerning what interdisciplinarity should be in economics: one, which emphasizes the need for exchange with "con-

\footnotetext{
${ }^{41}$ Loasby, 1999, p. 14.

${ }^{42}$ Potts 2000.

${ }^{43}$ An excellent discussion, in greater depth, on the characterization of open systems can be found in Chick and Dow, 2005. Also see Chick, 2004 and Neves, 2012b.

${ }^{44}$ Ardebili, 2005, p. 651.

${ }^{45}$ Ardebili says: "should represent".

${ }^{46}$ Ibid., pp. 653-654.

${ }^{47}$ On the concept of "ontological restriction" and on the crucial importance of our theories respecting what we believe to be the way the world works and without which it could not work as it works ("the way the world works constraint") see Mäki, 2001.
} 
tiguous" disciplines aimed at achieving a better understanding of the economic system, with each discipline maintaining its respective autonomy (let us call it the multidisciplinary model, the other, which advocates the need to transcend the current disciplines, moving towards a unified social science (this we shall call the transdisciplinary model).

Ronald Coase shall be taken to represent the first model. ${ }^{48}$ The transdisciplinary model was extensively developed by K. William Kapp ${ }^{49}$, but proposals along similar lines can be found in the work by various contemporary authors such as Geoffrey Hodgson and Tony Lawson or, closer to Kapp's own views, Clive Spash's contribution towards the integration of social, economic and ecological knowledge. ${ }^{50}$

For the multidisciplinary model, economics, and likewise the other social sciences, is a relatively separate discipline, with a specific object of study, a specific approach and/or an acquired set of research methods/techniques that are relatively consolidated. In the specific case of Coase, economics is considered to be the science that studies the "economic system", i.e. a set of activities directed at production, distribution and utilization of goods and services, which, in general, can be measured based on the measuring rod of money ${ }^{51}$, and the institutional framework in which they are placed ${ }^{52}$. Its focus is on the assessment of costs and benefits. However, in his view, the knowledge of the operation of the economic system also requires due consideration of the decisive influence of what is referred to as "extra-economic" factors such as property rights, the educational system or the State's regulatory activity - studied under other social sciences. The contribution of "contiguous" disciplines is thus considered to be of the utmost importance. The incursion of economists into the territories of the other social sciences, contrary to what happens in economic imperialism, thus arises mostly from the need for a better

\footnotetext{
${ }^{48}$ Coase analyzed the issue of interdisciplinarity in a small text, Economics and Contiguous Disciplines (Coase, 1994 [1977]), and enunciated his views on the topic of the interdisciplinary relations of economics in various more recent speeches and interviews (ISNIE Newsletter, several numbers).

${ }^{49} \mathrm{Kapp}$ addressed the topic of interdisciplinarity to considerable length in Toward a Science of Man in Society: A Positive Approach to the Integration of Social Knowledge (Kapp 1961), a book which is still fundamental, in my view, for reflection on this issue. His thoughts on interdisciplinarity can also be found in other texts, in particular those compiled in The Humanization of the Social Sciences (Kapp, 1985).

${ }^{50}$ Hodgson, 1996, Lawson, 2003 (chapter 6, especially 161-164) and Spash, 2012.

${ }^{51}$ As stated by Alfred Marshall (Principles of Economics, $9^{\text {th }}$ variourum ed., apud Coase 1994 [1977], p. 44): "the steadiest motive to ordinary business work is the desire for the pay which is the material reward of work. The pay may be on its way to be spent selfishly or unselfishly, for noble or base ends; ... but the motive is supplied by a definite amount of money: and it is this definite and exact money measurement of the steadiest motives in business life, which has enabled economics to outrun every other branch of the study of man."

${ }^{52}$ Firms and other organizational structures; markets of goods and services, labour and capital; the banking system; international trade etc.
} 
understanding of the economic system. Let us follow the rationale set forth by Coase: ${ }^{53}$

"Economists may $[\ldots]$ study other social systems, such as the legal and political ones, not with the aim of contributing to law or political science but because it is necessary if they are to understand the working of the economic system itself. [...] parts of these other social systems are so intermeshed with the economic system as to be as much a part of that system as they are of a sociological, political or legal system. [...] [T] he study by economists of the effects of the other social systems on the economic system will, I believe, become a permanent part of the work of economists. It cannot be done effectively by social scientists unfamiliar with the economic system. Such work may be carried out in collaboration with other social scientists but it is unlikely to be well done without economists. For this reason, I think we may expect the scope of economics to be permanently enlarged to include studies in other social systems. But the purpose will be to enable us to understand better the working of the economic system." (my emphasis)

In other words, without interdisciplinarity there is no adequate knowledge of the economic system, although the specialized contribution of the economists continues to be indispensable. In this perspective, scientific work requires a specialization which is still disciplinary.

At the other end of the spectrum, for the transdisciplinary model, the necessary integration of social knowledge requires transcending current disciplines. The rationale of this position is that the "essential unity of the object of study" of social sciences implies that specialization based on separate disciplines becomes inadequate and imposes that the present disciplinary compartmentalization evolve into a "unified [or integrated] science of man in society" (or "science of man and culture" ${ }^{54}$ ) with the replacement of the current disciplinary specialization by a thematic specialization. ${ }^{55}$

The underlying idea is that since there are no purely economic problems ${ }^{56}$, there cannot be any substantiated boundary lines separating economic analysis

\footnotetext{
${ }^{53}$ Coase, 1994 [1977] p. 46, my emphasis.

${ }^{54}$ Kapp, 1985, p. 16.

${ }^{55}$ Cf. Kapp, 1961, pp. 201-6.

${ }^{56}$ An issue that we know, at least since Marcel Mauss, with his notion of "total social fact", drew our attention to the insurmountable unity of the real object of social sciences and to the inexistence of a separable sector of social reality which we could call "economic" (see Nunes, 1976, p. 13). In this regard, Kapp, 1961, p. 201 wrote: “[T]here are no purely economic or political problems in the real world. The unreal character of the problems which are traditionally defined as economic or political becomes evident as soon as we realize that we cannot distinguish, for instance, between economic and noneconomic satisfactions or between economic objectives and the search for power in international politics."
} 
from the other related areas of social research. If, as Kapp argues, ${ }^{57}$ we still wish to stubbornly persist in keeping the traditional lines of demarcation between specialized social sciences, the outcome, almost inevitably, will be as follows:

"If the specialized disciplines nevertheless insist that the traditional lines of demarcation be maintained [...] [a]lmost inevitably the result will be that the preconceived perspective and method will determine the selection and definition of the problems to be investigated. Other problems which cannot be treated in this manner are likely to be ignored or shifted back and forth in the no-man's land between the disciplines. In short, instead of following the lead of the subject matter, the specialist $[. .$.$] is$ inclined to investigate only selected aspects of social events from the perspective and with the aid of the particular methodology which the discipline has preselected for him as appropriate and proper." (my emphasis)

That is: the problems investigated by the current specialized social sciences are, according to Kapp, partial and perhaps fictitious.

This is the case of economic analysis centred on the construction of a fictitious homo oeconomicus focused on the optimal choice (deemed "rational") between scarce resources in order to achieve exogenously determined goals and in a perspective of strictly "economic" calculation, ignoring any other type of considerations (ethical, political or others). To the contrary, Kapp argues for the need of unifying ("common-denominator") concepts (or integrating conceptual structures) which cross the different disciplines (and integrate everything that we know based on each discipline) - such as "man" 58 "culture" or "social structure" - and a holistic approach capable of taking into due account all the factors conditioning human behaviour. Indeed,

"No theory of human behavior which operates with single determinants (whether the pursuit of wealth, or any other 'drive') is likely to prove adequate for the explanation of human behavior at any level and under any of the various conditions under which man acts as a consumer, worker, entrepreneur, or member of a social or political group. In fact, any attempt to account for human conduct in terms of single drives or determinants can only yield an oversimplified picture of human behavior by singling out one factor from a number of determinants and attributing causal potency to it." (my emphasis $)^{59}$

Furthermore, Kapp upholds, the underlying rationale of economic calculation

\footnotetext{
${ }^{57}$ Kapp, 1961, p. 202.

${ }^{58}$ Nowadays we would say "human being".

${ }^{59}$ Kapp, 1985, p. 18.
} 
based on the comparison of costs and benefits according to market prices - the possibility of using the "measuring rod of money" which appears to be the justification for Coase of an autonomous economic science - is questionable as neither the costs of production recorded in firms accounts represent the total costs of production (the effective opportunity costs) nor do these prices reflect the true relative importance of human needs. And, therefore, the valuation of social costs and benefits based on market prices shall not provide a solid basis for the assessment of the desirable courses of action to be pursued.

Thus, the thorny issue of the boundaries between different social sciences shall ultimately revolve around the question of knowing to what extent the abstractions and theoretical constructions we draw up are adequate, or not, to the nature of the object of study. ${ }^{60}$

For the advocates of the model that we are analyzing there are no grounds for a distinctive economic science, separable from other social sciences. Reality (physical, biological and socio-cultural) is structured at increasingly higher levels of organization and complexity - inanimate matter, living bodies and human society - which, albeit connected and interrelated, are differentiated by emerging ${ }^{61}$ and irreducible properties from those of their lower level. Each emerging organization level, while constrained by its lower level(s), raises new questions and problems which cannot be adequately treated through recourse to the concepts and principles used to analyze another level or other levels. ${ }^{62}$ Social reality cannot be reduced to physical or biological explanations. A social science, distinctive from natural sciences, is necessary. Nothing, however, could justify the separation of "economic" problems relative to the rest of social reality. Lawson raises the matter as follows: ${ }^{63}$

"Have we identified an emergent realm of specifically economic phenomena, necessitating relatively distinct methods for their analysis? Clearly not. And it is not obvious that such is feasible. The social world, in all its aspects, turns upon human practice, the primary explanandum of social enquiry. And, whatever the practices of interest, amongst the explanans of social explanations are structures, positions, mechanisms,

\footnotetext{
${ }^{60}$ On this issue, Kapp draws attention to the need for the abstractions we make to be derived from observable behaviour - "real types", defined precisely as "abstraction[s] derived from observed regularities in behavior", "an image that simplifies and renders intelligible what at first sight appears unconnected and disparate in character" - rather than more or less useful fictitious constructions. For a more developed analysis of this topic, see Kapp, 1961, pp. 194-199.

${ }^{61}$ A level or stratum of reality is said to be "emerging" or with "emerging properties" when: (i) it develops from on a "lower" level, on which its existence depends and by which it is constrained; but that (ii) contains specific elements and "casual powers", irreducible to those governing the lower stratum and, therefore, are not fully predictable based on them, and might possibly retroact on the properties of the lower level (Lawson, 2003, pp. 44 and 161).

${ }^{62}$ Kapp, 1961, p. 75.

${ }^{63}$ Lawson, 2003, p. 162.
} 
processes and the like. In other words, there is no obvious basis for distinguishing economics according to the nature of its object, i.e. as a separate science. Nor does it have its own domain. [...] Its raison d'être is not a separate domain of distinct phenomena with their own properties, but a particular aspect of all social life."

It is now clear why, in the framework of this transdisciplinary model, the necessary division of intellectual work is shifted away from disciplinary specialization and towards a specialization focused on problems or problematic areas determined by their very nature ["follow [...] problems wherever they may lead"]. ${ }^{64}$

Kapp's own work on the problem of environmental disruption and social costs $^{65}$ or on the development issue ${ }^{66}$ provide good examples of such a problem-based approach.

On the development issue, Kapp wrote: ${ }^{67}$

"There is no autonomous problem of economic growth and development. As soon as we try to ascertain why some countries are 'underdeveloped' and others are not, we come upon interconnecting circles within a process of cumulative causation rather than purely 'economic' factors such as scarcities or shortages. In short, the so-called problem of economic development turns out to be not an economic problem but a socio-cultural and political problem involving far-reaching structural changes.” (my emphasis)

At the core of this argumentation is the idea of "cumulative causation", or cumulative dynamics, a crucial part in Kapp's own approach. These are the dynamics that ensure that the changes in any given substructure of the social system kinship and acculturation, production and distribution, political systems and noetic systems of thought, beliefs and values - are reflected in transformations of the social whole in the context of an open, circular and cumulative process of interaction and change. ${ }^{68}$ For this reason, it is argued that instead of an (additive) strategy of investigation of the parts, we should concern ourselves with the actual interaction between the parts and the whole - the network of social interconnections - in the context of a "comprehensive" or "holistic" approach". ${ }^{69}$ The so-called "econo-

\footnotetext{
${ }^{64}$ Kapp, 1961, pp. 205-6.

${ }^{65}$ Kapp, 1970a, 1970b and 1977a.

${ }^{66}$ Kapp, 1965 and 1977b.

${ }^{67}$ Kapp, 1961, pp. 201-2 (footnote).

${ }^{68}$ Kapp, 1961, chapter VI.

${ }^{69}$ Kapp, 1961, p. 180.
} 
mic" process should be perceived as an inevitably open system, an integral part of a much larger network of socio-cultural relations. ${ }^{70}$

It must be noted, to conclude, that, as Gunnar Adler-Karlsson acknowledged in his memorial essay in Kapp's honor, "[t]he creation of one synthetic science is certainly still far off”. ${ }^{71}$ Clive Spash, more recently, expressed a similar assessment. ${ }^{72}$

\section{FINAL COMMENTS}

Some basic ideas can be considered to have been established, based on the arguments presented throughout this text:

i. There is no distinctive and separable (real) object - the economy - which may be deemed as the particular property or domain of economists.

ii. Nonetheless, the division of intellectual labour is an undeniable necessity.

iii. Sciences are defined not only by the domain of the reality they wish to study or by the method used, but rather by their core interests and by the theoretical problematic they define - the questions they pose to themselves, the problems they aim to solve, in sum, their specific "theoretical object".

iv. As Coase argued, the study of the economy (and likewise the study of any other research area) requires some familiarization with the nature of the object of study. Economists, in the plurality of approaches that have characterized the discipline throughout the last two and a half centuries, have already acquired an extremely varied wealth of knowledge on aspects of social reality on which they have particularly focused their attention.

v. However, the "economic" is far too complex and interconnected with all the rest (from ecosystems to value and belief systems) to allow its enclosure within a discipline. Being an open system, the economy can be segmented into subsystems that may be analyzed as if they were closed systems, although any such segmentation should always be considered partial and provisional.

As Arena et al. stated: ${ }^{73}$, p. "If the economy is itself holistically open, any divi-

\footnotetext{
${ }^{70}$ Kapp's approach to the analysis of environmental disruption and development, based on cumulative causation, should be understood as a particular version of the more general transdisciplinary model that we have been considering. The latter does not stand or fall with the former.

${ }^{71}$ Adler-Karlsson, 1977, p. 85.

${ }^{72}$ In his words: "there is much reference to transdisciplinarity, although not that much evidence of it being put into practice (Spash, 2012, p. 35).

${ }^{73}$ Arena et al., 2009, p. 8.
} 
sion of the subject matter into disciplines is bound to be somewhat arbitrary, and also provisional. [...] The purpose of models, theories, and indeed disciplines, is to segment the subject matter so that we do not need to consider everything at once, or in only one way, but rather focus on particular aspects of the subject at hand. But these segmentations, to be useful in a holistic sense, need to be provisional rather than fixed. Thus, not only are models provisional closures as aids to thought, but so disciplinary boundaries are themselves provisional closures which we may want to change for the purposes of addressing particular aspects of economic reality."

The interdisciplinarity models that have been analyzed in the previous section, as we have noted, offer substantially different answers to the problem of knowing how to segment the reality object of study, with a view to enhancing the interconnections that we know exist in the real world (or at least minimise the loss resulting from disciplinary specialization). While the strategy of the multidisciplinary model is to open the disciplinary boundaries of economics with a view to gaining a better understanding of the "economic system" albeit, at the same time, preserving the autonomy of the discipline, the strategy we find in the more radical transdisciplinary model points towards the abandonment of disciplinary specialization, replacing it with a thematic specialization. The rationale of these two strategies should now be clear.

Regardless of the position upheld in relation to these two models, it is important at this point to stress that there is no single path for the practice of interdisciplinarity. As Brian Loasby states:

"Since our representations are always incomplete, innovation is always possible; we can change the set of elements, revise the internal linkages between them or redefine the external connections. Whether contemplating artefacts, processes, structures, sequences, problems or strategies, we are operating in large combinatorial spaces in which there are, in principle, many options for change. ${ }^{\prime 4}$

Such an idea of "innovation" and "combinatorial spaces" does capture well the open-systems approach I am supporting here: an approach that puts the emphasis on the dynamics of interaction of relatively separate disciplines that share important features among them. As I have argued elsewhere ${ }^{75}$ economics is in itself, like the economy that it studies, an open system and should be conceived as such (let us call this political economy).

To finalize, it is important to draw attention to the complex problem of the choices that, in any case, are raised by an interdisciplinary opening. In fact, there are innumerable obstacles to the practice of interdisciplinarity. Starting with insti-

\footnotetext{
${ }^{74}$ Loasby, 2003.

${ }^{75}$ Neves, 2012b.
} 
tutional obstacles. Science, from research to its teaching, including the criteria of recognition - with impact in terms of employment and career progression of teachers and researchers - and the funding system, is based on a disciplinary-based structure and tends to reproduce habits and practices that are intrinsically disciplinary. ${ }^{76}$ The system self-reproduces itself and, in a general fashion, tends to discourage practices of interdisciplinary innovation. ${ }^{77}$ And even when interdisciplinarity is "something that we want to do", ${ }^{78}$ we are frequently confronted with difficulties arising from the different disciplinary cultures and habits that are so deeply rooted, such as those related to ways of thinking and arguing in each discipline, language and assessment criteria about what does or does not merit attention and is capable of being recognised as being of scientific quality. ${ }^{79}$

Furthermore, the fact cannot be ignored that disciplines are very often crisscrossed with internal conflicts, which implies that interdisciplinary dialogue, in the context of social sciences, is not infrequently an effort, always difficult, of inter-paradigmatic intersection. For this reason, the discussion about interdisciplinarity must also be a discussion on pluralism in the context of science.

Interdisciplinarity is a long path to travel. What we can be certain of - and I think that this has been elucidated in this text - is that the economy, the reality that so many since Adam Smith (and many long before him) seek to understand, is far too complex and our cognitive limitations too important to leave the economy only to economists or to some sort of self-sufficient "economistic" approach. We need to recognise, first, the provisional nature of disciplinary boundaries. Secondly, that knowledge will always be incomplete and partial - there will always be missing connections. Sciences are open systems of knowledge. The utopian search for totality and unity-in-diversity will inevitably continue with us.

\section{REFERENCES}

Adler-Karlsson, Gunnar (1977) "Bioeconomics: A Coming Subject”, in Steppacher, Rolf; Zogg-Walz, Brigitte; Hatzfeldt, Hermann (eds.). Economics in Institutional Perspective: Memorial Essays in Honor of K. William Kapp. Lexington, Mass. and Toronto: Lexington Books, 85-92.

Ardebili, Morteza (2005) "Reorienting Economics, by Tony Lawson - Book Review”, Review of Social Economy, 651-657.

\footnotetext{
${ }^{76}$ It is crucial not to forget that each discipline, being an intellectual enterprise, is also an institutional structure with a specific history. It s evolution will depend not only on intellectual factors but also institutional and technical (in terms of research methods), being strongly conditioned by its history.

${ }^{77}$ This does not mean, of course, that scientific interdisciplinary innovation is precluded. As already seen earlier in this article, a number of important developments have always occurred in economics as a result of crossing-border dialogue.

${ }^{78}$ Pombo, 2004b, p. 20.

${ }^{79}$ On this issue it is worth reading two essential texts by Myra Strober on the experience of interdisciplinary dialogue carried out at three North American universities (Strober, 2006 and 2011).
} 
Arena, Richard; Dow, Sheila; Klaes, Matthias (2009) Open Economics: Economics in relation to other disciplines. London and New York: Routledge.

Arthur, Brian (2013) "Complexity Economics: A Different Framework for Economic Thought", Institute for New Economic Thinking (INET) Research Notes \#033 (available at http://ineteconomics. org/sites/inet.civicactions.net/files/Note-33-Arthur.pdf)

Becker, Gary (1976) The Economic Approach to Human Behavior. Chicago: University of Chicago Press.

Becker, Gary (1993) “Gary S. Becker - Prize Lecture: The Economic Way of Looking at Life”. (available at http://www.nobelprize.org/nobel_prizes/economic-sciences/laureates/1992/becker-lecture. html)

Chick, Victoria (2004) “On Open Systems”, Revista de Economia Política/Brazilian Journal of Political Economy, 24, 1 (93): 3-16.

Chick, Victoria; Dow, Sheila (2005) "The meaning of open systems", Journal of Economic Methodology, 12, 3: 363-381.

Coase, Ronald (1994 [1977]) "Economics and Contiguous Disciplines", in Coase, Ronald. Essays on Economics and Economists. Chicago: The University of Chicago Press, 34-46.

Davis, John (2006) “The turn in economics: neoclassical dominance to mainstream pluralism?”, Journal of Institutional Economics, 2, 1: 1-20.

Dequech, David (2012) "Economia e Sociologia Econômica: Abordagens, Objetos e Práticas”, in Kerstenetzky, Celia; Neves, Vítor (eds.). Economia e interdisciplinaridade(s). Coimbra: Edições CES/ Almedina, 149-172.

Diamond, Peter; Vartiainen, Hannu (eds.) (2007) Behavioral Economics and its Applications. Princeton e Oxford: Princeton University Press.

Downs, Anthony (1957) An economic theory of democracy. New York: Harper and Row.

Fine, Ben (1997) “The new revolution in Economics”, Capital \& Class 61: 143-148.

Fine, Ben (2002) “'Economic Imperialism’: a view from the periphery”, Review of Radical Political Economics, 34: 187-201.

Fontana, Magda (2009) The Santa Fe Perspective on Economics: emerging patterns in the science of complexity, WP CESMEP Working paper No. 08/2009 (available at http://www.cesmep.unito.it/ WP/2009/8_WP_Cesmep.pdf)

Frey, Bruno; Benz, Matthias (2004) "From imperialism to inspiration: a survey of Economics and psychology", in Davis, John et al. (eds.). The Elgar Companion to Economics and Philosophy. Cheltenham: Edward Elgar, 61-83.

Graça, João Carlos; Lopes, João Carlos (2010) "Complexidade, interdependência e autonomia em sistemas económicos e sociais”, Revista Crítica de Ciências Sociais [Online], 90 | 2010 (available at http://rccs.revues.org/1777)

Groenewegen, Peter (2007) Alfred Marshall: Economist 1842-1924. Hampshire, UK e Nova York: Palgrave Macmillan. [Portuguese translation: Alfred Marshall, Lisbon: Actual Editora, 2011]

Hirshleifer, Jack (1985) “The Expanding Domain of Economics”, The American Economic Review, 75, 6: 53-68.

Hodgson, Geoffrey (1996) “Towards a Worthwhile Economics”, in Medema, Steven; Samuels, Warren (eds.). How Economists Should Do Economics. Aldershot: Edward Elgar, 103-21.

Hodgson, Geoffrey (2001) How economics forgot history: the problem of historical specificity in social science. London and New York: Routledge.

Hodgson, Geoffrey (2008) "Marshall, Schumpeter and the shifting boundaries of economics and sociology", in Shionoya, Yuichi; Nishizawa, Tamotsu (eds.). Marshall and Schumpeter on Evolution: Economic Sociology of Capitalist Development. Cheltenham, UK; Northampton, MA, USA: Edward Elgar.

Holt, Richard; Rosser, Jr., Barkley; Colander, David (2011) “The Complexity Era in Economics”, Review of Political Economy, 23, 3: 357-369.

Ingham, Geoffrey (1996) "Some recent changes in the relationship between economics and sociology", Cambridge Journal of Economics, 20: 243-275. 
Kapp, K. W. (1961) Toward a Science of Man in Society: A Positive Approach to the Integration of Social Knowledge. The Hague: Martinus Nijhoff.

Kapp, K. W. (1965) "Economic Development in a New Perspective: Existential Minima and Substantive Rationality", Kyklos, 17, 1: 49-79.

Kapp, K. W. 1970a) "Environmental disruption: General issues and methodological problems”, Social Science Information, 9, 4: 15-32.

Kapp, K. W. (1970b) "Environmental Disruption and Social Costs: a Challenge to Economics”, Kyklos, 23, 4: 833-48.

Kapp, K. W. (1976) “The Open-System Character of the Economy and its Implications", in Dopfer, Kurt (ed.). Economics in the Future. Londres: The Macmillan Press, 90-105.

Kapp, K. W. (1977a) "Environment and Technology: New Frontiers for the Social and Natural Sciences”, Journal of Economic Issues, 11, 3: 527-539.

Kapp, K. W. (1977b) "Development and Environment: Towards a New Approach to Socioeconomic and Environmental Development”, in Steppacher, Rolf; Zogg-Walz, Brigitte; Hatzfeldt, Hermann (eds.), Economics in Institutional Perspective: Memorial Essays in Honor of K. William Kapp. Lexington, Mass. and Toronto: Lexington Books, 205-218.

Kapp, K. W. (1985), The Humanization of the Social Sciences, organized by Ullmann, John; Preiswerk, Roy. Lanham: University Press of America.

Kerstenetzky, Celia (2012), “Economia e Ética: a virada normativa?”, in Kerstenetzky, Celia; Neves, Vítor (eds.). Economia e interdisciplinaridade(s). Coimbra: Edições CES/Almedina, 55-76.

Kerstenetzky, Celia; Neves, Vítor (eds.) (2012) Economia e Interdisciplinaridade(s). Coimbra: Almedina.

Lawson, Tony (2003) Reorienting economics. London and New York: Routledge.

Lazear, Edward (2000) “Economic Imperialism”, The Quarterly Journal of Economics, 115, 1: 99-146.

Loasby, Brian (1999) Knowledge, Institutions and Evolution in Economics. London and New York: Routledge.

Loasby, Brian (2003) “Closed models and open systems”, Journal of Economic Methodology, 10, 3: 285-306.

Mäki, Uskali (1992) "On the Method of Isolation in Economics”, Poznan Studies in the Philosophy of the Sciences and the Humanities, 26, 317-351.

Mäki, Uskali (2001) "The way the world works (www): towards an ontology of theory choice", in Mäki, Uskali (ed.). The Economic World View: Studies in the Ontology of Economics. Cambridge: Cambridge University Press, 369-389.

Mäki, Uskali (2004) "Theoretical isolation and explanatory progress: transaction cost economics and the dynamics of dispute", Cambridge Journal of Economics, 28, 319-346.

Mirowski, Philip (1991) "The When, the How and the Why of Mathematical Expression in the History of Economics Analysis", The Journal of Economic Perspectives, 5, 1: 145-157.

Neves, Vítor (2010) “O que é afinal o 'económico'? A Economia como ciência moral e política”, in Neves, Vítor; Caldas, José (eds.). A Economia Sem Muros. Coimbra: Edições CES/Almedina, 3144.

Neves, Vítor (2012a) “A análise dos custos sociais em Ronald Coase e K. William Kapp: duas perspectivas sobre a economia e a interdisciplinaridade”, in Kerstenetzky, Celia; Neves, Vítor (eds.). Economia e interdisciplinaridade(s). Coimbra: Edições CES/Almedina, 125-147.

Neves, Vítor (2012b) "Sciences as Open Systems - The Case of Economics", in Pombo et al. (eds.). Special Sciences and the Unity of Science. Dordrecht: Springer, 205-217.

Nunes, A. Sedas (1976 4ª ed.) Questões Preliminares sobre as Ciências Sociais. Lisbon: Gabinete de Investigações Sociais.

Pombo, Olga (2004a) “Epistemologia da interdisciplinaridade”, in Pimenta, Carlos (Ed.). Interdisciplinaridade, Humanismo, Universidade. Porto: Campo das Letras, 93-124.

Pombo, Olga (2004b) Interdisciplinaridade: Ambições e Limites. Lisbon: Relógio d'Água.

Posner, Richard (1972 1st edition) Economic Analysis of Law. Boston: Little, Brown and Company. 
Potts, Jason (2000) The New Evolutionary Microeconomics: Complexity, Competence and Adaptive Behaviour. Cheltenham: Edward Elgar.

Santos, Ana (2010) “Terá chegado o tempo dos arquitectos e designers económicos?”, in Neves, Vítor; Caldas, José (eds.). A Economia Sem Muros. Coimbra: Edições CES/Almedina, 117-138.

Santos, Ana (2012) "Entre a Economia e a Psicologia: comportamento e experiências", in Kerstenetzky, Celia; Neves, Vítor (eds.). Economia e interdisciplinaridade(s). Coimbra: Edições CES/Almedina, 173-196.

Spash, Clive (2012) "Towards the Integration of Social, Economic and Ecological Knowledge", in Gerber, Julien-François; Steppacher, Rolf (eds.). Towards an Integrated Paradigm in Heterodox Economics: Alternative Approaches to the Current Eco-Social Crises. Basingstoke, Hampshire: Palgrave Macmillan, 26-46.

Strober, Myra (2006) "Habits of the Mind: Challenges for Multidisciplinary Engagement”, Social Epistemology: A Journal of Knowledge, Culture and Policy, 20, 3-4: 315-331.

Strober, Myra (2011) Interdisciplinary conversations: challenging habits of thought. Stanford, CA: Stanford University Press.

Sugden, Robert (2001) “The evolutionary turn in game theory”, Journal of Economic Methodology, 8, 1: $113-130$.

Velthuis, Olav (1999) “The Changing Relationship Between Economic Sociology and Institutional Economics: From Talcot Parsons to Mark Granovetter", American Journal of Economics and Socio$\log y, 58,4:$ 629-649.

Swedberg, Richard (1990) “The New 'Battle of Methods”, Challenge, 33, 1: 33-38.

Vaggi, Gianni; Groenewegen, Peter (2003) A Concise History of Economic Thought From Mercantilism to Monetarism. Hampshire, UK and New York: Palgrave Macmillan.

Van Damme, Eric (1999) "Game Theory: the Next Stage,” in Kirman, A.; Gérard-Varet, L-A. (eds.). Economics Beyond the Millennium. Oxford: Oxford University Press, 184-214. 